\title{
Assertive training on discipline of learning in junior high school
}

\author{
Tri Dewantari $\left.{ }^{*}\right)$, Rita Eka Izzaty \\ ${ }^{12}$ Universitas Negeri Yogyakarta \\ *)Corresponding author, ఏe-mail: dewantaritri@gmail.com
}

\begin{abstract}
Discipline in learning is the obedience of students in the implementation of learning. In reality, in schools there are still students who behave inappropriately with the rules agreed upon in learning such as: often chatting in the classroom, not doing homework, not coming to school. Seeing the phenomenon so that there are efforts to improve student learning discipline. The purpose of this study is to determine the discipline of student learning and to determine the level of effectiveness of the use of assertive training in improving student learning discipline. The method used in this research is quasi-experimental research with Non-equivalent Control Group Design. The results show that $t$ count $>t$ table (6.652> 2.145). So, Ho conclusion refused and $\mathrm{Ha}$ accepted, which means assertive training can improve student learning discipline.
\end{abstract}

Keywords: assertive training, dicipline of learning

How to Cite: Dewantari, T., Izzaty, RE. (2018). Assertive training on diciplineof learning in junior high school. Couns-Edu: International Journal of Counseling and Education, 3(2): pp. 57-62. DOI: https://doi.org/10.23916/0020180313120

This is an open access article distributed under the Creative Commons Attribution License, which permits unrestricted use, distribution, and reproduction in any medium, provided the original work is properly cited. (C2017 by author and Indonesian Counselor Association (IKI).

\section{Introduction}

Education is an important thing that is always related to human life. Every living human being needs education to improve his quality of life. The purpose of national education based on Law No. 20 of 2003 that is for "the development of potential learners to become human beings who believe and be cautious about God Almighty, have a noble character, healthy, knowledgeable, capable, creative, independent, and become citizens a democratic and responsible state" (Indonesia, 2003). Based on these objectives it can be concluded that the purpose of education is to form the character and personality of students and to improve the potential and abilities that exist in the students, so that students can direct their lives to conform to the norms and rules that apply, it so that learners can become qualified and responsible human resources.

In achieving the desired goals for the learning process, there are many factors that influence, among others, the physical factors and psychological factors, which include motives, interests, attention concentration, balance, personality, self convidence, self discipline, integration and memory (Dani, Suarni, \& Sulastri, 2013). Discipline is a very important factor in learning required by each student (Amri, 2013; Sanjaya, 2016). Discipline as a requirement in shaping behavior in life (Raharjo, 2010; Reza \& Dirgantara, 2010), which will lead a student in learning, improve learning ability that affect the personality of learners (Angkowo \& Kosasih, 2007; Choridah, 2013; Siagian, 2013). 
However, based on facts in the field, not all learners follow the rules and regulations set by the school (Hidayat, 2013). Violations committed by learners are increasing from time to time (Rismayanthi, 2011). Violations of school rules by students related to discipline include late school entry; not wearing full school attributes; carrying cigarettes and smoking in the school environment; and then cheating behavior (Sayekti, 2012). Based on Joko Sumanto's research that there are some violations that occur in school discipline are as follows: in the odd semester percentage of students not attending school as much as $0.13 \%$ (32 cases students overdue more than 10 minutes, 76 cases students violation of school uniform, 5 cases of fights between students, 1 case of theft, 4 cases asking for money to other students as many as 4 cases, and 16 cases leaving lessons without permission 16 cases) (Oktariana, 2012). While in the even semester, the percentage of students did not attend school without information / alpa of 0.09\% (31 cases of students late over 10 minutes, 81 cases of school uniform violations, 4 cases of fights between students, 1 time theft, 2 cases asking for money to other students by coercion, and 20 cases skipping and leaving lessons without permission).

Cases of discipline are also found in one of the Vocational High Schools in Lampung. Based on data in one of the vocational schools there are 155 learners late more than 10 minutes as many as 112 cases, due to the distance home to a distant school; 18 school offenses such as, (1) do not wear uniforms and attributes in accordance with the provisions (Aprilia, 2013), because students forget to bring attributes, follow friends, follow the trend (Rizqiyani \& Suwarno, 2018); (2) fighting, because of defending friends, and feeling disturbed (Hasanah \& Kumalasari, 2015; Isnaeni Rahmawati, 2017; Yuniati, Suyahmo, \& Juhadi, 2017); (3) playing cards in the classroom, because learners feel there is a chance, and follow friends (Kusuma \& Aisyah, 2012); (4) against teachers, due to lack of respect for learners towards teachers (Machin, 2014); and (5) smoking, due to trend (Lonto, 2015; Muhajirin, 2016; Pratiwi, 2009; Rahmasari, 2015); and leave lessons without permission (Damayanti \& SETIAWATI, 2013; Fitriani, 2017; Ibrahim, 2015) as much as two cases such as playing play station around the school environment due to follow friends (Acetylena, 2013; Damayanti \& SETIAWATI, 2013; Graciani, 2011; Ida Rahmawati, 2013). Based on the data, it is apparent that there are still disciplinary problems that occur.

To respond to the problem of the learning discipline encountered one can do with using counseling services. One of the counseling guidance services techniques used with training techniques aserti, because based on the survey most of the students discipline violations because of the invitation of friends and because want to be recognized by friends. This is supported by the opinion of Corey which states that assertive training can be used to help individuals who have difficulty in expressing feelings, be honest, clear and open but without harming, harming, and offending others (Corey, 2003). In assertive training, learners can explain and tell their desires honestly, clearly, and openly but still in accordance with prevailing norms so as not to harm other people / the environment around them.

This is reinforced by the research of Dani, et.al which states that assertiveness training can improve the learning discipline of learners (Dani, et al., 2013). The use of assertive exercise is important to know the extent of the influence of assertive training and introduce assertive training strategies in improving the learning discipline of learners. In addition, the use of assertive training is expected to help learners to express their desires, be honest with the perceived, able to reject the invitation of friends to commit disciplinary offenses, and instill a sense under responsibility as a learner.

\section{Method}

The research design used in this research is quasi experimental (Creswell, 2010; Sugiyono, 2008). The design used is Non-equivalent Control Group Design. In this design the experimental group and the control group are equally given pre-test and post-test. However, only the experimental group given treatment. Population in this research is the student of X grade at SMK Trisakti Bandar Lampung which amounted to 155 students. Sampling technique in this research is by using purposive sampling technique. The criteria of sampling are learners who have a learning discipline in the low category. Based on the result of questionnaire of rating scale, there were 18 students who will be divided into two groups, namely nine students in the experimental group who will be given treatment using counseling service of assertive training group and nine students in the control group who were not given treatment using assertive training but still controlled its development. 
Data collection techniques used in this study by using scale scalescalescale method, rating scale scale used to obtain information the extent to which the discipline learners learners in certain categories / positions. In addition there are techniques of data collection support in the form of documentation methods, interviews. The stages or procedures of assertive exercise used in this study are: (a) rational strategy; (b) identify the circumstances that cause problems, as for the counselor to ask the counselee to openly discuss the problems encountered and something done or thought when the problem arises; (c) distinguishing assertive and non-assertive behavior; (d) playing roles to provide feedback and better modeling of behavior; (e) termination and termination of assertive training.

The data analysis technique used in this research is by using Wilcoxon Test is an improvement from sign test, because in this research test Pretest and posttest using SPSS (Statistical Package for Social Science) version 16. Based on wilcoxon test using SPSS 16 program, obtained level of significance, with qualification if sig. $<0.05$ then Ho is rejected and $\mathrm{Ha}$ accepted, meaning there is an increase in student learning discipline after being given treatment with assertive training.

\section{Results and Discussions}

Based on the result of calculation of pretest and posttest average in the experimental group and control group both experienced an increase, in the experimental group $(59,333,78,111)$ and in the control group $(60,778,68,889)$. Description of the results as contained in the following table:

\begin{tabular}{ccc}
\hline No. & Experimental group & Control group \\
\hline$\sum \mathbf{1}$ (first treatment) & 59 & 60 \\
Average & 333 & 778 \\
$\Sigma \mathbf{2}$ (second treatment) & 78 & 68 \\
Average & 111 & 889 \\
\hline
\end{tabular}

However, although both groups both experienced an increase, but the experimental group's average score was higher and the experimental group experienced a higher increase compared to the control group, it can be seen from the posttest result of the experimental group larger than the control group $(78,111$ and 68,889 ). Thus, it can be concluded that after the provision of counseling services group assertive training of learners have increased learning discipline.

Thus, it can be concluded that after the provision of counseling services group assertive training of learners have increased learning discipline. Based on the results of research that has been done shows that the discipline of learning is mostly in the high category but there are still students who are in the category of medium and low. So that if left unchecked it can be a hindrance in the learning process both for the learners, as well as the people (teachers, other learners, and school), because one that can overcome barriers in the learning process is to have a disciplined learning behavior.

Discipline study in this research is divided into two aspects, namely aspects of time discipline and aspects of discipline deeds (Wiyono, 2011). Learning discipline is expected to form or train the personality patterns of learners, as a tool for adjustment in learning. Discipline conditions learners learn based on the percentage of discipline aspects of learning are as follows: (1) time discipline (80.91\%); and (2) discipline of action $(80.25 \%)$. This indicates that the discipline of learners lies in the low category in the discipline aspect of action, while the highest percentage of discipline learning is in the aspect of time discipline. However, it can be improved by using continuous exercises/practices, so that learners can control the behaviors performed to conform to the prevailing rules. The time discipline behavior experienced an increase in this is indicated by the percentage of time discipline aspect in the pretest experimental group greater than the post-test $(3.98 \% \leq 5.27 \%)$, and in the control group the percentage of time discipline indicator at the time of pretest is greater than post-test $(4.25 \% \leq 4.49 \%)$. After the posttest of discipline behavior, the time of improvement is seen in the percentage of discipline aspects of action in the pre-test 
experimental group greater than the posttest $(3.89 \% \pm 5.11 \%)$, and in the control group the percentage of time discipline indicator at the time of pretest is more large from the posttest $(3.92 \% \leq 4.57 \%)$. Based on these calculations, it can be said that counseling services assertive training group is more effective to improve the behavior of discipline learning.

Assertive training activities conducted in this study using group dynamics. According to Corey an assertive group of 8-10 members has the same background, the therapist acts as a group leader and roleplaying, coach, reinforce and role model (Corey, 2003). Refraction behavior of learning discipline is enhanced by using assertive training because with assertive training the learners can practice/role play according to the subject matter of the given discipline. In addition, to improve assertive behavior in learning disciplines such as assertiveness in learning, responsibility as a student, honesty and not blame others to the discipline of learning, as well as respect for teachers and regulations in the school environment, can be improved by using assertive training because learners are helped to express their anger or aggravation, exhibit overpowering modesty and always encourage others to precede it, have difficulty in saying no, difficulty expressing affirmations and other positive responses, and feeling they have no right to express their opinions and opinions.

\section{Conclusions}

Based on the objectives, the results of research discussion, it can be concluded as follows: the description of the discipline of learning in the learner that there are $11.61 \%$ of students who are in the medium category, which means that learners have shown the behavior of discipline of learning but not fully/continuously performed which is characterized by: (a) learners have been able to run disciplinary behaviors of time so that learners have the firmness and willingness to follow the lesson and learn in a timely manner; (b) learners are able and have a disciplined attitude to the time so that learners have the firmness and willingness to follow the lesson and learn on time, collect and complete tasks on time; (c) learners are able and have attitude of discipline deed, learners will feel guilty if violation of discipline learn, so have been able to obedient and not defying regulation, not lazy in learning, do not tell others to work for her, do not lie for profit herself, doing a pleasant behavior.

Overall this study yields the conclusion that assertive training is effective in improving the learning discipline of learners. The effectiveness of assertive exercise is characterized by an increase in the learning discipline of learners. This can be seen from the differences and the comparison between the pretest and posttest results.

\section{Acknowledgments}

Thank you to the supervisor, the dean of Yogyakarta State University, and the friends who have helped the process of this research. This manuscript is the result of research that researchers do in Lampung province.

\section{References}

Acetylena, S. (2013). Analisis Implementasi Kebijakan Pendidikan Karakter Di Perguruan Taman Siswa Kecamatan Turen Kabupaten Malang. Jurnal Kebijakan dan Pengembangan Pendidikan, 1(1).

Amri, S. (2013). Pengembangan dan model pembelajaran dalam kurikulum 2013. Jakarta: Prestasi Pustaka. Angkowo, R., \& Kosasih, A. (2007). Optimalisasi media pembelajaran: Gramedia Widiasarana.

Aprilia, F. (2013). Hubungan Antara Kecerdasan Interpersonal dengan Perilaku Kenakalan Remaja pada Siswa SMA N 1 Grobogan. Journal of Social and Industrial Psychology, 2(1).

Choridah, D. T. (2013). Peran Pembelajaran Berbasis Masalah untuk Meningkatkan Kemampuan Komunikasi dan Berpikir Kreatif serta Disposisi Matematis Siswa SMA. Infinity Journal, 2(2), 194202.

Corey, G. (2003). Teori dan praktek konseling dan psikoterapi. Alih bahasa oleh E. Koswara. Bandung: PT Refika Aditama.

Creswell, J. W. (2010). Research design pendekatan kualitatif, kuantitatif, dan mixed. Yogyakarta: Pustaka Pelajar. 
Damayanti, F. A., \& SETIAWATI, D. (2013). Studi tentang Perilaku Membolos pada Siswa SMA Swasta di Surabaya. Jurnal Psikologi,(Online), 3(01).

Dani, I. P., Suarni, N. K., \& Sulastri, M. S. (2013). Efektivitas Konseling Behavioral Teknik Latihan Asertif Untuk Meningkatkan Perilaku Disiplin Belajar Siswa Kelas X SMA Laboratorium Undiksha Tahun 2012/2013. Jurnal Ilmiah Bimbingan Konseling Undiksha, 1(1).

Fitriani, F. (2017). Study Penanganan Guru Bk Terhadap Perilaku Membolos Siswa Di Smp Kecamatan Wiyung di Kota Surabaya. Jurnal BK UNESA, 7(1).

Graciani, W. (2011). Perilaku Membolos Siswa (Studi Deskriptif Kualitatif tentang Perilaku Membolos Siswa di SMP Negeri 2 Delanggu, Kecamatan Delanggu, Kabupaten Klaten). Universitas Sebelas Maret.

Hasanah, N., \& Kumalasari, D. (2015). Penggunaan Handphone dan Hubungan Teman pada Perilaku Sosial Siswa SMP Muhammadiyah Luwuk Sulawesi Tengah. Harmoni Sosial: Jurnal Pendidikan IPS, 2(1), 55-70.

Hidayat, S. (2013). Pengaruh Kerjasama Orang Tua Dan Guru Terhadap Disiplin Peserta Didik Di Sekolah Menengah Pertama (Smp) Negeri Kecamatan Jagakarsa-Jakarta Selatan. Jurnal ilmiah widya, 1(1).

Ibrahim, A. S. (2015). Hubungan Antara Motivasi Belajar Dengan Perilaku Membolos Pada Siswa Kelas VIII SMP Batik Surakarta. Universitas Muhammadiyah Surakarta.

Indonesia, P. R. (2003). Undang-undang Republik Indonesia nomor 20 tahun 2003 tentang sistem pendidikan nasional.

Kusuma, F. W., \& Aisyah, M. N. (2012). Implementasi Model Pembelajaran Kooperatif Tipe think pair share untuk meningkatkan aktivitas belajar akuntansi siswa kelas XI IPS 1 SMA Negeri 2 Wonosari tahun ajaran 2011/2012. Jurnal Pendidikan Akuntansi Indonesia, 10(2).

Lonto, A. L. (2015). Pengembangan Model Pendidikan Karakter Berbasis Nilai Sosio-Kultural pada Siswa SMA di Minahasa. MIMBAR, Jurnal Sosial dan Pembangunan, 31(2), 319-327.

Machin, A. (2014). Implementasi Pendekatan Saintifik, Penanaman Karakter dan Konservasi pada Pembelajaran Materi Pertumbuhan. Jurnal Pendidikan IPA Indonesia, 3(1).

Muhajirin, N. (2016). Strategi Mengatasi Perilaku Merokok Siswa Kelas VIII SMP Bhineka Karya Boyolali dengan Pendekatan Konseling Eklektik Tahun Pelajaran 2014/2015. Karya Ilmiah Mahasiswa FKIP, 2(1).

Oktariana, Y. (2012). Program Bimbingan Pribadi Sosial Menggunakan Assertive Training Untuk Meningkatkan Disiplin Diri Siswa. Universitas Pendidikan Indonesia.

Pratiwi, R. A. (2009). Hubungan Antara Konsep Diri dan Konformitas dengan Perilaku Merokok pada Remaja. Universtas Sebelas Maret.

Raharjo, S. B. (2010). Pendidikan Karakter Sebagai Upaya Menciptakan Akhlak Mulia. Jurnal Pendidikan dan Kebudayaan, 16(3), 229-238.

Rahmasari, W. R. (2015). Identifikasi Perilaku Sosial Dalam Pembelajaran Penjasorkes Pada Siswa Kelas III SD Negeri Minomartani 1 Kabupaten Sleman. Kediri (ID): Universitas Nusantara PGRI Kediri.

Rahmawati, I. (2013). Pola Pembinaan Santri Dalam Mengendalikan Perilaku Menyimpang Di Pondok Pesantren Sabilul Muttaqin, Desa Kalipuro, Kecamatan Pungging, Mojokerto. Jurnal Kajian Moral dan Kewarganegaraan, 306-320.

Rahmawati, I. (2017). Identifikasi Perilaku Sosial Dalam Pembelajaran Penjasorkes Pada Siswa Kelas III SD Negeri Minomartani 1 Kabupaten Sleman. Fakultas Ilmu Keolahragaan.

Reza, R. A., \& Dirgantara, I. (2010). Pengaruh gaya kepemimpinan, motivasi dan disiplin kerja terhadap kinerja karyawan PT Sinar Santosa Perkasa Banjarnegara. Universitas Diponegoro.

Rismayanthi, C. (2011). Optimalisasi Pembentukan Karakter dan Kedisiplinansiswa Sekolah Dasar Melalui Pendidikan Jasmani Olahraga dan Kesehatan. Jurnal Pendidikan Jasmani Indonesia, 8(1).

Rizqiyani, S., \& Suwarno, S. (2018). Implementasi Ekstrakurikuler Pencak Silat Dalam Menanamkan Karakter Disiplin Dan Cinta Tanah Air Pada Siswa Kelas V SD NU Nawa Kartika Kudus Tahun 2017. Universitas Muhammadiyah Surakarta.

Sanjaya, D. H. W. (2016). Penelitian tindakan kelas: Prenada Media.

Sayekti, I. C. (2012). Pembelajaran IPA Menggunakan Pendekatan Inkuiri Terbimbing Melalui Metode Eksperimen dan Demonstrasi Ditinjau dari Kemampuan Analisis dan Sikap Ilmiah Siswa. INKUIRI, 1(2). 
Siagian, R. E. F. (2013). Pengaruh minat dan kebiasaan belajar siswa terhadap prestasi belajar matematika. Jurnal Formatif, 2(2), 122-131.

Sugiyono, M. P. K. (2008). kualitatif dan R\&D. Bandung: Alfabeta, 124.

Wiyono, J. (2011). Pengaruh Pemberian Sanksi dan Hadiah terhadap Kedisiplinan Siswa Mengerjakan Tugas di SDN 1 Sudimoro Tulung Klaten. Universitas Muhammadiyah Surakarta.

Yuniati, A., Suyahmo, S., \& Juhadi, J. (2017). Perilaku Menyimpang dan Tindak Kekerasan Siswa SMP di Kota Pekalongan. Journal of Educational Social Studies, 6(1), 1-6. 